\title{
MATERIALS TO THE HISTORY OF KHARKOV CLINIC ESTABLISHED BY DOCTOR G.A. DAVIDOVICH (1895-1920)
}

\author{
K.V. Rusanov \\ Independent researcher \\ 8 Kosmonavtov St., Ap. 12, Kharkiv, 61103, Ukraine \\ tel.: +38 (068) 607-64-93 \\ e-mail: kokamoka51@gmail.com \\ ORCID 0000-0001-6580-2387
}

\author{
E.G. Rusanova \\ Engineer \\ Science and Research Laboratory of Quantum Biology \\ and Quantum Medicine \\ V.N. Karazin Kharkiv National University \\ 4 Svobody Sq., Kharkiv, 61022, Ukraine \\ tel.: +38 (093) 849-41-35 \\ e-mail: kokamoka51@gmail.com \\ ORCID 0000-0001-9820-122X
}

Rationale and purpose of the study. At the end of XIX century, in Kharkov, a large private clinic was opened, with modern equipment for physiotherapy. Its work, the names of employees and the role in the development of urban medicine are poorly and unclearly highlighted in the literature. The purpose of the work is to establish according to the source materials the main stages of the history of the hospital and the names of the doctors who played key roles in it.

Sources. The study used annual guides published in Kharkov (city and special medical) and in St. Petersburg ("Russian Medical List”), "Lists of students of the Imperial Kharkov University"; "Kharkov Medical Journal", the newspapers "Kharkov Provincial Gazette" and "Southern Region".

Results. It is established that the surgical clinic with an in-patient facility was opened in Kharkov in 1893; the head of the department was the doctor G.A. Davidovich, and the resident physician was P.A. Litsyn, both graduates of Kharkov University. In 1895, G.A. Davidovich became the owner of the clinic (including its building), and P.A. Litsyn became the head; the list of services was added with the treatment of internal and nervous diseases. During the years 1896-1898, a new three-story building was built for the hospital with a special project, and emphasis in its equipment was placed on water treatment and phototherapy. Here, one of the first in Russia electric light baths invented in the early 1890s by an American physician D.H. Kellogg, were installed.

However, in the same year of 1898, G.A. Davidovich died, and the clinic was inherited by his widow Sophia; P. Litsyn remained the head of the department. In 1899, doctor B.I. Spivakov, who graduated from the Kharkov University, was admitted to work in the hospital. Over the next 20 years, yesterday's student made a great contribution to the further development of the hospital as a physiotherapy hospital.

After the nationalization of the clinic by the Bolsheviks, it became a city hospital, where P.A. Litsyn and B.I. Spivakov continued to work. The latter became an assistant professor, and in 1930 the head of the department of physiotherapy of the Institute for Advanced Training of Physicians. In the mid-1920's, on the basis of the former clinic of Davidovich, the Ukrainian Institute of Physiotherapy and Balneology was opened.

Conclusion. The hospital of Davidovich, and especially its employee B.I. Spivakov played a significant role in the development of Kharkov medicine, especially in the improvement of physical methods of treatment.

Key words: history of physiotherapy, Kharkov, hospital, electric light baths, doctors, G.A. Davidovich, P.A. Litsyn, B.I. Spivakov.

\section{МАТЕРІАЛИ ДО ІСТОРІЇ ХАРКІВСЬКОЇ ЛІКАРНІ, ЗАСНОВАНОЇ ЛІКАРЕМ Г.А. ДАВИДОВИЧЕМ (1895-1920 рр.)}

К.В. Русанов ${ }^{1}$, G.Г. Русанова ${ }^{2}$

${ }^{1}$ Незалежний дослідник, м. Харків, Украйна;

${ }^{2}$ Харківсъкий національний університет імені В.Н. Каразіна,

Науково-дослідна лабораторія квантової біологї та квантової медицини, м. Харків, Украӥна

Обгрунтування і мета дослідження. У кінці XIX ст. в Харкові відкрилася велика приватна лікарня, оснащена сучасним обладнанням для фізіотерапії. Її робота, імена співробітників і роль у розвитку міської медицини слабо і неясно висвітлені в літературі. Мета роботи - встановити за першоджерелами основні етапи історії лікарні та імена лікарів, які відіграли в ній ключові ролі.

Джерела. У дослідженні використані щорічні довідники, видані в Харкові (загальноміські та спеціальні медичні) і в Петербурзі ( «Російський медичний список»), «Списки студентів Імператорського 
Харківського університету»; «Харківський медичний журнал», газети «Харківські губернські відомості» $\mathrm{i}$ «Південний край».

Результати. Встановлено, що хірургічна лікарня зі стаціонаром відкрилася у Харкові в 1893 р.; завідувачем служив лікар Г.А. Давидович, а ординатором - лікар П.А. Ліцин, обидва - випускники Харківського університету. У 1895 р Г.А. Давидович став власником лікарні (включаючи і її будівлю), а П.А. Ліцин - завідувачем; в перелік послуг було додано лікування внутрішніх і нервових хвороб. За 1896-1898 рр. для лікарні був побудований новий триповерховий будинок за спеціальним проектом, а при іï обладнанні зроблений акцент на водолікування та світлолікування. Тут були встановлені одні з перших в Росії електросвітлові ванни, винайдені на початку 1890-х рр. американським лікарем Д.Х. Келлогом.

Однак у тому ж 1898 р. Г.А. Давидович помер, і лікарня перейшла до його вдови Софії; завідувачем залишився П.А. Ліцин. У 1899 р. на роботу в лікарню був прийнятий лікар Б.І. Співаков, який закінчив Харківський університет. За 20 наступних років вчорашній студент вніс великий внесок у подальший розвиток лікарні саме як фізіотерапевтичного стаціонару.

Після націоналізації лікарні більшовиками вона стала міською лікарнею, де продовжували працювати П.А. Ліцин і Б.І.Співаков. Останній став доцентом, а в 1930 р. - завідувачем кафедрою фізіотерапії Інституту удосконалення лікарів. В середині 1920-х рр. на базі колишньої лікарні Давидовича відкрився Український інститут фізіотерапії та курортології.

Висновок. Лікарня Давидовича і особливо її співробітник Б.І. Співаков зіграли значну роль в розвитку харківської медицини, особливо в удосконаленні фізичних методів лікування.

Ключові слова: історія фізіотерапії, Харків, лікарня, електросвітлові ванни, лікарі, Г.А. Давидович, П.А. Ліцин, Б.І. Співаков.

\section{МАТЕРИАЛЫ К ИСТОРИИ ХАРЬКОВСКОЙ ЛЕЧЕБНИЦЫ, УЧРЕЖДЕННОЙ ВРАЧОМ Г.А. ДАВИДОВИЧЕМ (1895-1920 гГ.)}

\section{К.В. Русанов ${ }^{1}$, Е.Г. Русанова ${ }^{2}$}

${ }^{1}$ Независимый исследователь, г. Харьков, Украина;

${ }^{2}$ Харьковский национальный университет имени В.Н. Каразина,

Научно-исследовательская лаборатория квантовой биологии и квантовой медицины, г. Харьков, Украина

Обоснование и цель исследования. В конце ХIX ст. в Харькове открылась крупная частная лечебница, оснащенная современным оборудованием для физиотерапии. Ее работа, имена сотрудников и роль в развитии городской медицины слабо и неясно освещены в литературе. Цель работы - установить по первоисточникам основные этапы истории лечебницы и имена врачей, сыгравших в ней ключевые роли.

Источники. В исследовании использованы ежегодные справочники, изданные в Харькове (общегородские и специальные медицинские) и в Петербурге («Российский медицинский список»), «Списки студентов Императорского Харьковского университета»; «Харьковский медицинский журнал», газеты «Харьковские губернские ведомости» и «Южный край».

Результаты. Установлено, что хирургическая лечебница со стационаром открылась в Харькове в 1893 г.; заведующим служил врач Г.А. Давидович, а ординатором - врач П.А.Лицын, оба - выпускники Харьковского университета. В 1895 г. Г.А. Давидович стал владельцем лечебницы (включая и ее здание), a П.А.Лицын - заведующим; в перечень услуг было добавлено лечение внутренних и нервных болезней. За 1896-1898 гг. для лечебницы было построено новое трехэтажное здание по специальному проекту, а при ее оборудовании сделан акцент на водолечении и светолечении. Здесь были установлены одни из первых в России электросветовые ванны, изобретенные в начале 1890-х гг. американским врачом Д.Х.Келлогом.

Однако в том же 1898 г. Г.А.Давидович умер, и лечебница перешла к его вдове Софье; заведующим остался П.А.Лицын. В 1899 г. на работу в лечебницу был принят врач Б.И.Спиваков, окончивший Харьковский университет. За 20 последующих лет вчерашний студент внес большой вклад в дальнейшее развитие лечебницы именно как физиотерапевтического стационара.

После национализации лечебницы большевиками она стала городской больницей, где продолжали работать П.А.Лицын и Б.И.Спиваков. Последний стал доцентом, а в 1930 г. - заведующим кафедрой физиотерапии Института усовершенствования врачей. В середине 1920-х гг. на базе бывшей лечебницы Давидовича открылся Украинский институт физиотерапии и курортологии.

Заключение. Лечебница Давидовича и особенно ее сотрудник Б.И.Спиваков сыграли значительную роль в развитии харьковской медицины, особенно в усовершенствовании физических методов лечения.

Ключевые слова: история физиотерапии, Харьков, лечебница, электросветовые ванны, врачи, Г.А. Давидович, П.А. Лицын, Б.И. Спиваков. 
In 1998, twenty years ago, the first issue of the journal "Photobiology and Photomedicine" was published in Kharkov. It contained an article by Professor L.D. Tondiy [1] on how phototherapy was developing in our city, starting from the 1860 s when, according to Leonid Dmitrievich, the scientists of Kharkov University, who were at the origins of the organization of the resort "Berezovsky Mineral Waters", offered to use sun treatment in the period of recovery.

Later the leading place in photomedicine was taken by artificial - electrical - light therapy. In his article L.D. Tondiy [1] referred the peak of this tendency in Kharkov to the 1920s-1930s. During this period, the Ukrainian Institute of Physiotherapy and Balneology (until 1934), and then the Ukrainian Institute of Experimental Physiotherapy (until 1937) functioned in our city. Specialists in light therapy were trained by the Department of Physiotherapy of the Ukrainian Institute for Advanced Training of Physicians (currently Kharkov Medical Academy of Postgraduate Education), where professor E.A. Chernikov and Associate Professor B.O. Spivakov worked. In Kharkov, the First (1925) and the Third (1935) All-Union congresses of physiotherapists were held. [1]

Due to the constant interest of Professor L.D. Tondiy in the history of photomedicine, we took up the solution of a number of forgotten or controversial issues of the past, related to phototherapy in Kharkov. We managed to make a more accurate picture of the first period of the formation of the Berezovsky Mineral Waters, to find information about some forgotten light-therapy rooms that operated in Kharkov in the 1900s, and so on. [2-4]

In the times of the Russian Empire, phototherapy in our city was used by doctors who were the owners of private phototherapeutic rooms or complex clinics, which included such offices. Kharkov citizens borrowed methods of treatment with light and equipment for it either abroad, or in representative offices of foreign manufacturers in Russia.

The popularity of phototherapy among doctors and patients was facilitated by the well-known success of the Dane N.R. Finsen, the Nobel Prize winner in Physiology and Medicine in 1903, awarded to him "in recognition of his merits in the treatment of diseases - especially lupus - with the help of concentrated light radiation". Thanks to this award and well-organized PR, the Finsen's method was known as the only theoretically grounded method of phototherapy. Therefore, the
Kharkov doctor N.P. Sudeykin [3] not coincidentally named his light therapy office as Finsen in advertising.

There were dozens of private hospitals and medical offices in Kharkov; in the 1900s-1910s approximately half of them offered certain types of light therapy. At the same time, because of competition, most of the private hospitals and offices in the city had huge financial difficulties; their owners often changed, they closed and reappeared.

On this unsteady, unstable background, "The clinic established by Dr. G.A. Davidovich" on the Blagoveshchensk street (until recently - Karl Marx) remained the symbol of stability in our city for many years. And in it, of course, there was a light therapy room (Fig. 1) equipped with equipment modern at the time.

However, the project of G.A. Davidovich did not immediately acquire a physiotherapeutic profile; at first, it was a purely surgical hospital. Its transformation is described in the book I.Ю. Робак "Організація охорони здоров’я в Харкові за імперської доби (початок XVIII cm. - 1916 p.)". [5] However, the author of this monograph almost did not provide exact dates, confining of terms like "first", "later", "soon", etc. He did not report the address of the Davidovich's clinic, nor the names of the doctors who worked in it or the biography its founder Grigory Abramovich Davidovich.

According to I.Yu. Robak, the Davidovich's clinic held its genealogy from the "Surgical clinic established by Professor V.F. Grube" on the Blagoveshchensk street in 1890. University surgeon V.F. Grube was the founder and director of this medical institution, but the actual owner of the latter was named by I.Yu. Robak as G.A. Davidovich. [5] Later (when?) the clinic was named after Dr. Davidovich; the latter soon died, but "managed to open a hydropathical establishment in a neighboring building (which?) and equip it with popular at that time imported hydrotherapeutic devices. The institution was named "Hydropathical establishment and clinic of the widow of Dr. S.V. Davidovich", its owner not only continued her husband's business but also expanded it. In a separate building (the third?) there

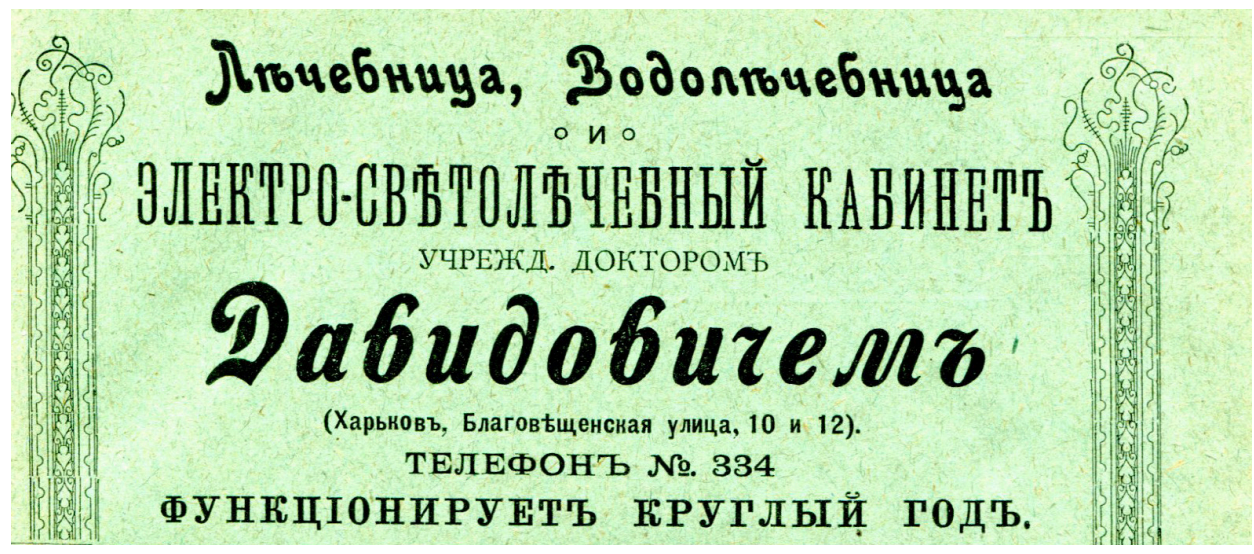

Fig. 1. Fragment advertising the hospital Davidoviche from the directory "All of Kharkov" second half of the 1900's. 
was a boarding house for mentally disabled patients. Treatment of sexual disorders was started. For the hydropathical establishment, the baths and showers of all existing systems and other new equipment were purchased". [5]

$$
* * *
$$

It is possible to clarify this complicated question only by relying on the facts cited in the original sources. What was the purpose of our research.

In the "List of students of the Imperial Kharkov University for the 1880-1881 academic year", Davidovich Grigory Abramovich, a Jew from the merchant class, was under number 14 in the medical department among the students in the fourth year, who entered the university on August 16, 1876 after the graduation of the Third Kharkov gymnasium. From other sources, it is known that the student Davidovich was born in 1856. But his birthplace is not indicated, so we have no reason to consider Grigory Abramovich (sometimes - Avramovich) as a Kharkovite.

G.A. Davidovich gained a doctor's diploma in 1882. In addition, the annual "Russian Medical Lists" reported that in the late 1880 s he practiced freely in the city of Lugansk, Ekaterinoslav province, and in the early 1890s he was a doctor of the Lugansk city training school and obtained a rank of a collegiate assessor. G.A. Davidovich moved to Kharkov no earlier than the end of 1892 . Here he was considered a freely practicing physician up to 1897 , inclusive, after which he was permanently withdrawn from the lists. Grigory Abramovich was never a doctor of medicine.

Urban annual reference books "Kharkov Calendar" for 1890-1892 did not report the existence of a "Surgical Clinic established by Professor V.F. Grube". The first mention of it was made in the "Kharkov calendar" in 1893:

"Surgical clinic established by prof. V.F. Grube (Blagoveshchenskaya Str., 12). The head of the clinic is Dr. G.A. Davidovich, the resident doctor is Dr. P.A. Litsyn.

There is room for 25 surgical patients. In addition to separate rooms, there are common chambers. The operations are carried out by the founder and director Prof. V.F. Grube. Payment for operations and premises is agreed. At the hospital, there is one free bed, and there are two for emergency cases".

This information is repeated in the "Kharkov calendars" for 1894-1895.

Neither V.F. Grube nor his above-mentioned employees were then owners of houses on the Blagoveshchenskaya Street. According to the "Lists of landlords of Kharkov for 1890", house number 10 belonged to the heirs of Captain A.P. Strakhov, and house number 12 - the noblewoman E.N. Boguslavskaya.

Apparently, the famous Kharkov surgeon V.F. Grube (1827-1898) chose G.A. Davidovich and P.A. Litsyn as employees of the hospital because he knew them and trusted them. He probably remembered these doctors as his students at the university.

However, we did not find the data on the medical specialization of Grigory Davidovich (and his interest in physiotherapy). But P.A. Litsyn exactly was a surgeon: in advertising of his home appointment, he invited patients with surgical and dental diseases. At the same time he worked in the hospital on the Blagoveshchensky Street for over 30 years and, of course, became part of its history.

From the "List of students of the Imperial Kharkov University for the 1879-1880 academic year" it can be seen that Pavel Litsyn, born in 1854 and being a fifth-year student, was of the Orthodox faith, came from a merchant class, graduated from a gymnasium in Taganrog and, on August 16, 1874, he entered the medical department and studied at his own expense. "Russian medical lists" reported on P.A. Litsyn that, having received a doctor's diploma in 1880, he remained to live in Kharkov, where he worked as a railway doctor.

Pavel Anastasievich was born in a Taganrog merchant family which originated from Greek immigrants: his father was a merchant of the Third Guild, who traded "red goods", and his mother, born Makropulo, was the daughter of a rich Taganrog merchant.

The road to the medical faculty in Kharkov was laid for Pavel by his elder (13 years) brother Nikolai Litsyn (1841-1920), who got a medical diploma in our university in the 1860s. N.A. Litsyn went to work in his native city, where he became famous - though not so much in medical, as other activities. For a long time he was the chairman of the first Mutual Credit Society in Taganrog, the foreman of the Taganrog exchange committee; was the head of city training schools; from 1872 he was elected as a member of the town council (in the meeting room of which his portrait was posted), and from 1897 to 1905 he was the city head of Taganrog.

In addition, Nikolai Litsyn rose to the "general" rank of an actual state councillor, had the Order of St. Anna of the 2nd degree, the Order of St. Vladimir of the 3rd degree, etc.

However, his brother Pavel was much more modest. He did not have real estate in Kharkov and lived in a rented apartment on the Ekaterinoslavskaya street (now the Poltava route), in the house No. 37. P.A. Litsyn did not rise to ranks, and he did not get a doctor's degree. He avoided politics, which later contributed to the longevity of the doctor.

In contrast to him, G.A. Davidovich, who was at first the hired manager of the "Surgical Hospital", launched activities aimed at moving the latter into his own hands. Most likely, he did this with the consent of the already very old V.F. Grube.

As can be seen from the "List of homeowners of Kharkov" in 1895, Grigory Abramovich bought the house No. 10 on the Blagoveshchenskaya street with an estimated value of 3120 rubles. (the owner of the house No. 12, valued at 12060 rubles, remained 
E.N. Boguslavskaya). At the same time, G.A. Davidovich registered a new charter of the clinic through the authorizing bodies, where he himself was already the owner (Fig. 2).

On November 29, 1894, the charter was approved by the Minister of the Interior and the Director of the Medical Department. Here are some fragments from this document (there are more than 20 clauses in it):

" 1 . The hospital was established with the aim of delivering medical aid, accommodation, care and maintenance that meet modern requirements of science for patients, especially for non-residents, for a moderate charge, as well as aseptic and antiseptic requirements for operated patients.

2. The clinic consists of an outpatient facility and rooms both general and separate for the placement of inpatients; there is also an operating room equipped with all kinds of instruments; laboratory for the preparation of sterilized material and disinfectant liquids; the insulation room; a special room for admitting visiting patients, a pharmacy (without the right to free sale) with the medicines required to provide initial assistance; a bathroom, electrical appliances and so on.

3. The hospital belongs to Dr. G.A. Davidovich who is the head of the clinic; in addition, it involves one or two permanent resident physicians who visit patients twice a day at certain times or more, if necessary, at any time; and there is a sufficient staff of experienced servants in the clinic. $<\ldots>$

5. Persons of both sexes of all ages are admitted as inpatients at all times, and the female patients are placed in rooms separate from men: a) with diseases requiring surgical assistance, including eye, urogenital and gynecological diseases, with a department for obstetric cases; b) with internal diseases. The incoming patients are admitted daily at certain times.

6. The insane patients and those suffering from acute infectious diseases (typhoid, smallpox, diphtheria, etc.) are not admitted to the institution. If any of those admitted to the hospital have this kind of disease, then his relatives and the administration must take measures to remove such a patient from the hospital. If this proves impossible, then such a patient must be transferred to an isolation room at the clinic.

7. Every patient entering the clinic is required to submit a legalized residence permit, which, upon presentation to the police, is kept by the head of the clinic and returned to the patient upon his exit from the clinic. $<\ldots>$

9. Every patient admitted to the hospital enjoys full ready maintenance and treatment, such as: a room, lighting, table and bed linen, food, servants, baths and bandages and all the medical aids of the clinic, as well as advice and care of the entire medical staff. In addition, the patient uses the library, magazines, newspapers of the clinic, and other entertainment permitted for patients. With the permission of the head, the patients can use the clothes, linen and bed brought

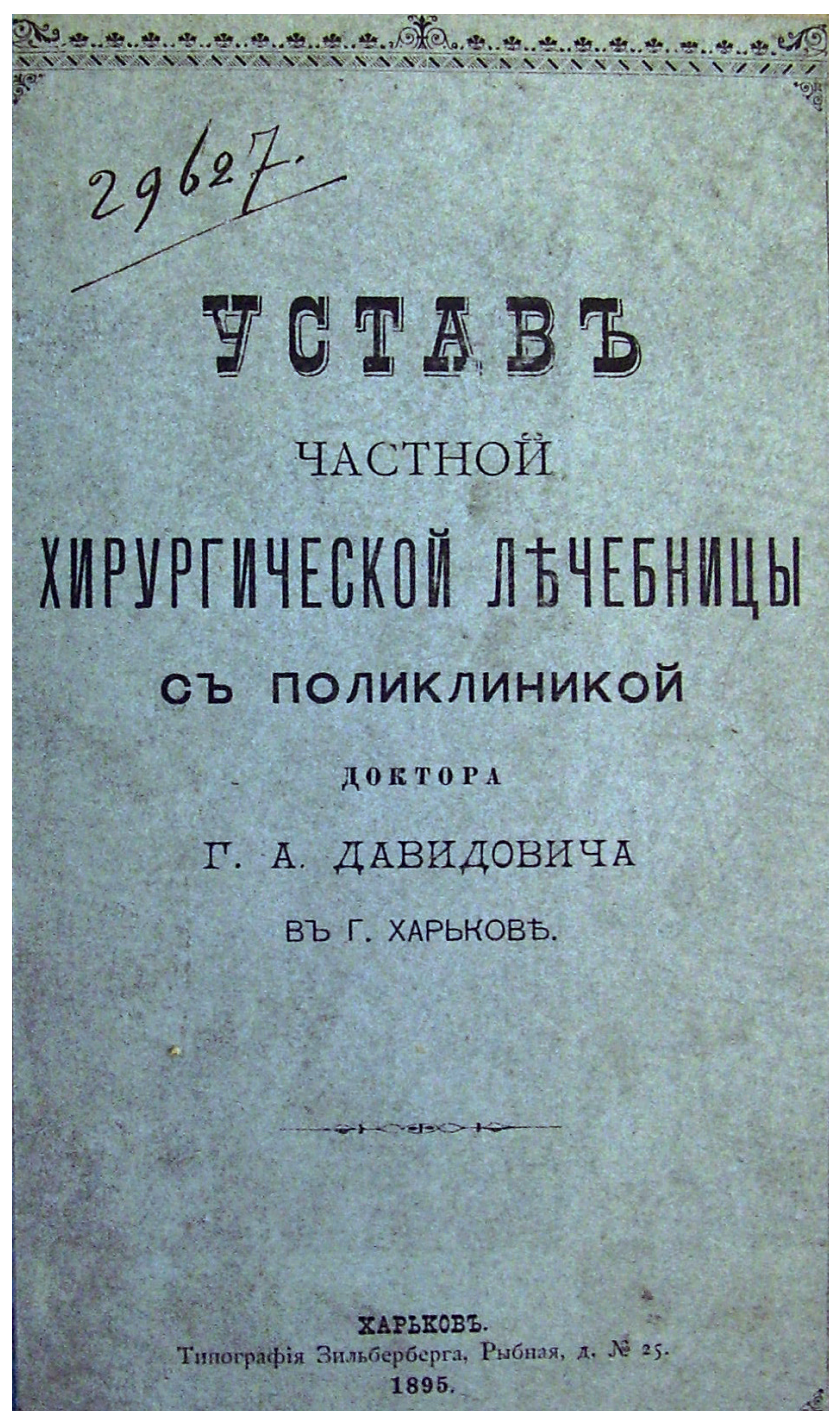

Fig. 2. The cover of the statute of the clinic G.A Davidovich [6]

with them but, in this case, all these things must be preliminarily subjected to thorough disinfection in a device specially designed in the hospital for this purpose. $<\ldots>>$

12. Payment for maintenance, medical care, dressings and dressing material, baths and others at the indication of a specialist who treats this patient, is determined by mutual agreement. Its size (from 2 rubles 50 kopecks a day and 60 rubles per month) depends on the complexity and difficulty of treating a certain case, the patient's requirements, the degree of his material well-being and the duration of his stay in the clinic. Accordingly, as well as the scientific interest, in this case, one and not more than two patients can be also taken free of charge. The fee is paid by patients in advance when they enter the hospital for all the period determined for him or her in the clinic or for 10 days. In the event that the patient leaves the institution before the expiration of the term, the fee is returned back to him with the calculation.

13. In the event of the death of a patient and the absence of relatives, the clinic takes appropriate measures to bury the deceased at its own expense and 
promptly notifies the Medical Department and the police about each death case. The document of the deceased, as well as the remaining money and things, is forwarded to the proper institution". [6]

The other paragraphs of the charter of the clinic contained the rules for carrying out the operations; registration of patients and their deposit of clothing, money and things. It was reported on the regular supervision of the hospital by the governor and the provincial medical department, the need to report annually on its activities. It was required from patients to observe the regime established in the clinic "in the forms of successful activities"; meetings with relatives were permitted provided that the visitors gave in the clothes and all the things brought for disinfection.

Information about the opened clinic, published in the "Kharkov calendar" for 1896, added several new details to the charter:

"The hospital of Dr. G.A. Davidovich (Blagoveshchenskaya Str., 12). Senior resident Dr. P.A. Litsyn.

The hospital accepts patients with the following diseases: a) surgical, including for operations of the eye, genitourinary and female organs, and b) internal and nervous. The clinic can accommodate up to 32 patients with separate rooms. Two beds are free; one of them is for eye diseases named after prof. L.L. Girschman."

In addition, in this guide, it was reported that G.A. Davidovich lives on the Blagoveshchenskaya Street, in his own house No. 10.

The above data (repeated in the "Kharkov calendars" in 1897 and 1898) showed that at first in the "clinic of Dr. Davidovich" the physiotherapeutic methods of treatment by no means dominated: the baths and electric appliances were mentioned in the charter tangentially.

$$
* * *
$$

However, during these years Grigory Abramovich rebuilt his own house No. 10 - in fact, he built in its place a new three-story building, specially designed for the hospital of physiotherapy profile. City guide, printed in early 1898 , was published before the opening of the latter, and the newspapers were the first which told the Kharkovites about this event.

"Kharkov Province Gazette" published such a note on August 6, 1898:

"A large therapeutic institution will be opened soon in Kharkov on Blagoveshchenskaya street - a hydropathic clinic of Dr. Davidovich, built with all sorts of devices for treating with water, electricity, steam, gymnastics, massage, etc.

The entire building with a water-raising tower with a height of 35 arshins was built by the city architect Dashkevich.

The interior is characterized with the elegance of the decoration and comfort. The bathing room is designed in Moorish style with waterproof floors and walls and with the latest ventilating devices. In this room, besides the pool, there are baths of all kinds and purposes, ranging from simple bathing ones to such novelties in the field of electrotherapy as an electric light bath for sweating. There are also various tools for general, local showers etc. For those who do not want to use the baths in the common room, there are several isolated rooms.

In addition to hydrotherapy, the new clinic will widely use electrotherapy, for which there are various special devices.

The heating of the clinic is steam-electric, and the lighting is electric, for which there is own electric generator. For visitors or seriously ill, a boarding house is arranged. The hospital is administered by the doctors Dikansky and Litsyn."

"Southern Region" on October 14, 1898, reported the opening of the hydropathic clinic of Dr. G.A. Davidovich already post factum, noting in particular that "for the first time in Russia, carbon dioxide and electric light baths are used" in it.

Electric light (otherwise - photoelectric) baths were invented in the early 1890s by an American physician John Harvey Kellogg. According to the Soviet textbook of physiotherapy, these devices were a multi-faceted box-cupboard (Fig. 3). [7] The patient was sitting inside the bath on a chair; in the upper lid, there was a neck slot for the head to be outside during the procedure. On the inner surface of the bath, there were incandescent lamps (usually coal, of 16 or 25 candles) with reflectors made of metal mirrors or milk glass tiles. The lamps could be switched on in various amounts and combinations to achieve the desired effect.

This was considered to be profuse sweating coming faster and at a lower temperature than in a hot air-dry bath. A strong effect of electric light baths was attributed to the "direct effect on the body of radiant energy in the form of infrared and visible rays of numerous light bulbs". [7]

D.H. Kellogg (see below about him) reported on the favorable results he achieved with this method in case of obesity, diabetes and the Bright disease (nephritis). Electric light baths quickly gained popularity in Europe; they began to treat other metabolic diseases (for example, gout), poisoning, rheumatism, even heart diseases and bronchial asthma.

The manufacturers of medical electrical equipment have developed the designs of electric light baths with more efficient use of radiant energy due to the special form of lamps and reflectors. In Russia, representative offices of Western companies offered electric light baths of "intensive" class at a price of up to 1500 rubles - Radiotherm (Reiniger, Gebbert and Schall) and Polysol (Sanitas)

Even at the turn of the century, local electric light baths were used widely enough - to affect any one part of the body; there is every reason to think that they 

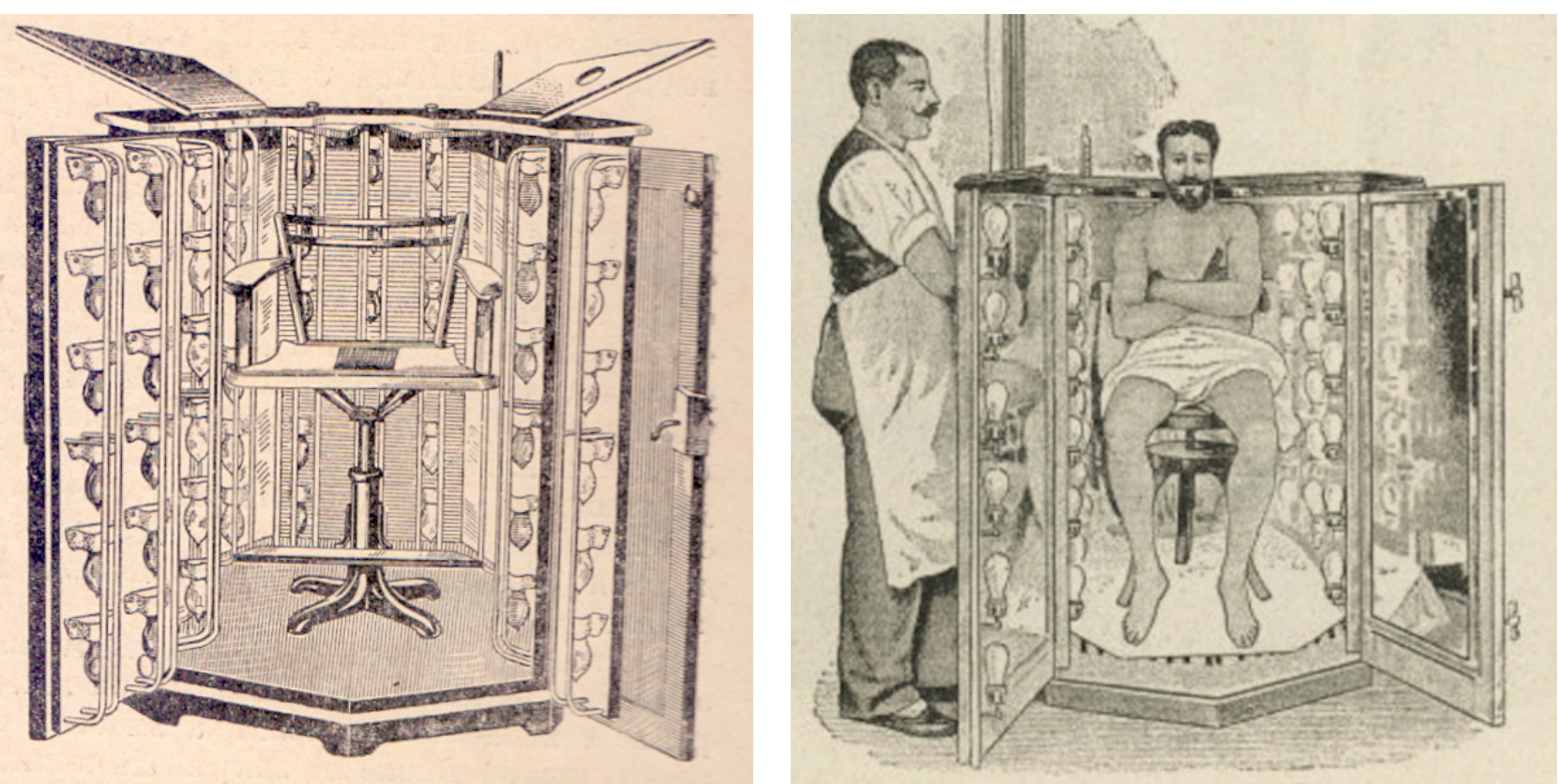

Fig. 3. General electrolight bath: on the left - a picture from the book [7]; right - American advertising early XX century

were available in the hospital of Davidovich. These devices, also equipped with incandescent lamps, had a different size and shape (Fig. 4). It is easy to see that they were prototypes of modern devices for phototherapy of the diabetic foot syndrome, where miniature light-emitting diodes are used as radiation sources.

But back to the newspaper note, to pay attention to two important details. The new building of the clinic was designed by Mikhail (Mitrofan) Irodionovich Dashkevich, the city architect in Kharkov since 1893. By the way, it had an estimated value of 33,300 rubles which was more than 10 times more expensive than the one bought by G.A. Davidovich (data from the "List of homeowners of Kharkov" in 1909, where the owner was the widow of collegiate assessor Sofya Vladimirovna Davidovich).

Grigory Abramovich himself was named in the "Provincial Gazette" only as the founder of the institution, whereas the directors were Litsyn and Dr. Dikansky already known to us. Yakov Lazarevich (Eleazarovich) Dikansky, of the same age as G.A. Davidovich, entered the medical faculty of Kharkov University in 1880 , four years later. At the same time Ya.L. Dikansky was a fellow countryman of P.A. Litsyn in Taganrog, he also was from a merchant, but Jewish family. Having received a doctor's degree in internal medicine in 1886, Yakov Lazarevich settled in Kharkov for the next 30 years. He was engaged almost all the time in private practice at Yaroslavskaya str., 2.

Most likely, Ya.L. Dikansky, personally acquainted with P.A. Litsyn and G.A. Davidovich, was the head of the clinic because Grigory Abramovich died by the middle of 1898, or could no longer work. And the sonheir of the founder, Alexander Grigorievich Davidovich, was still a boy: he was born in 1888 and got a doctor's degree in nervous diseases in 1916. [8] So the clinic was re-registered with Sofya Vladimirovna, while continuing to be called "established by Dr. G.A. Davidovich".

Ya.L. Dikansky, a decorative figure, was soon replaced in the hospital by other doctors. It's advertising in the guide (Fig. 5) contained their surnames: A.A. Govseev and B.O. Spivakov. [9]

"Alphabetical list of students of the Imperial Kharkov University" for the autumn semester of 1893-1894 reported that the student Alexander Gosveev, of a Jewish faith, was studying at the third year of the medical faculty and granted relief from fees for learning by the University Board.

According to the "Russian Medical Lists", Alexander Akimovitch Gosveev was born in 1872, gained the title of a physician for internal diseases in 1895, after which he was a supernumerary resident physi-

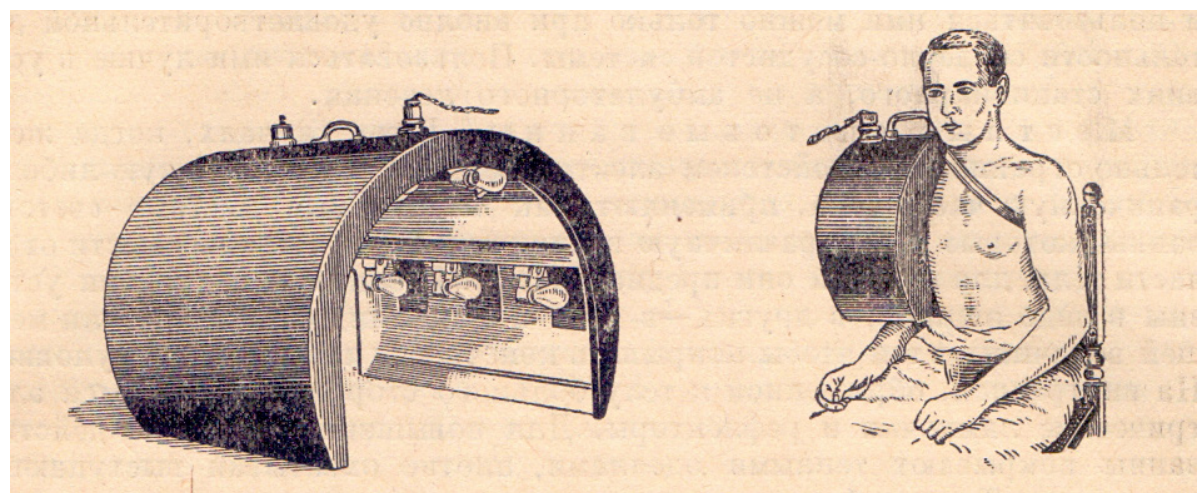

Fig. 4. Apparatus for local electrolight baths [7]: on the left — for the trunk and legs of the patient; right — for the shoulder joint 
cian of the clinic (probably university) for several years in Kharkov. He had two older brother-doctors (one of them was a doctor of medicine), who lived in other cities.

Without having any kindred support in Kharkov (and, apparently, craving for physical methods), Gosveev Jr. did not stay long in the Davidovich hospital. Already in 1903 he was a territorial sanitary doctor in Lugansk, later engaged in private medical practice in Yekaterinoslav (with his brother Albert), and in 1915 he was the head of the territorial sanitary bureau in Kiev.

The future associate professor Boris Osipovich Spivakov was a completely different person, who was noted by L.D. Tondiy in the article. [1] Unfortunately, later on, Leonid Dmitrievich added very little to Spivakov's description. In the last work it was noted only that "in 1930 the Department of Physiotherapy (in Kharkov) was headed by B.O. Spivakov, an experienced therapist and balneologist, who was the head of the hydropathic institution in the building No. 10 on Karl Marx street (Blagoveshchenskaya) and worked in the scientific council of the Kharkov Scientific Society". [10]

But today we can already say that the Davidovich's hospital was the first (and desired!) place of service for the young doctor Boris Spivakov after graduating from Kharkov University. Over the years of work in this private medical institution, Spivakov grew into an ideological leader, we believe that it was he (and not the nominal head, the surgeon Litsyn) that determined the direction of the development of the clinic.

From the "List of students of the Imperial Kharkov University," it is clear that the student Spivakov Bention Iosifovich was born on June 13, 1875, in Odessa, a Jewish middle-class family, graduated from the Third Odessa City Gymnasium and on September 6, 1894, entered the Medical Department.

In 1897, he studied in the third year, and in 1899 received a doctor's degree in internal and nervous diseases. In 1901 a talented Odessa resident lived in
Fig. 5. Fragment of the reference book [9]

Kharkov at the address: Blagoveshchenskaya str., 10, that is, directly at the place of work. [9]

It is known that he often went abroad to the conference on physical methods of treatment and, having returned, he made reports for his colleagues in Kharkov about new products in this area. So, on May 18, 1913, B.I. Spivakov reported on the topic "Radium therapy and electrotherapy at the 4th Congress on Physiotherapy in Berlin" at a meeting of the Kharkov Medical Society.

Actually, the formulary list of Bention Iosifovich Spivakov, the resident of the private clinic of Davidovich in Kharkov, which was compiled in 1911, is kept in the Russian State Historical Archive (Fund 1349 , inventory 2, portfolio 404, sheets 71-73). Now it is beyond our reach, but in Soviet times it was not so difficult to look at this document. 


$$
* * *
$$

On the bookshelf in the office of Boris Spivakov on the Blagoveshchenskaya street, 10, there certainly was the fundamental work of the inventor of electric light baths (Fig. 6).

Dr. D.H. Kellogg was not a hereditary physician, his father had a factory in the town of Battle Creek (Michigan) for making brooms. But the young John refused to make brooms, he graduated from the Medical Department of New York University and for half a century (1877-1929) published many books about a healthy lifestyle and treatment. According to Dr. Kellogg, electric light baths 2-3 times a week were the means not only of treating many diseases and purifying the body of harmful substances but, along with vegetarianism, etc., a part of the correct way of life. His book on light therapy is available in the Internet today.

Dr. Kellogg had a portfolio of three-volume "Rational Hydrotherapy: A manual of the physiological and therapeutic effects of the hydratic procedures and the technique of their application in the treatment of disease" republished more than once, and a more frugal in a number of sheets work "The Art of Massage: Practical manual for the student, the nurse and the practitioner". Both in 1901 (Fig. 5) and in 1914, when the advertisement of the Davidovich hospital was published, shown in Figure 7, and water treatment (hydrotherapy), and massage were included in the range of means at the disposal of B.I. Spivakov. Boris

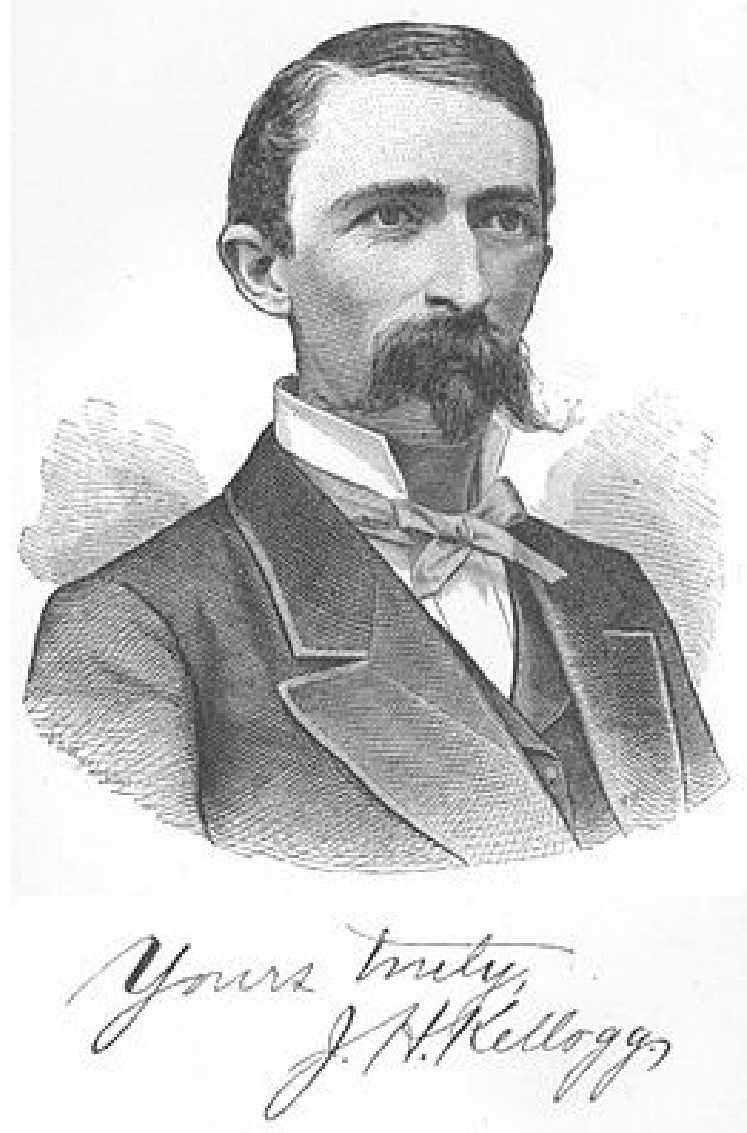

Iosifovich, who had now risen to the position of the head of the water-electro-light-healing hospital, simply had to have these manuals as handbooks.

The author of the latter was a personality that was vivid and attractive in its own way, albeit ambiguous. So, John Kellogg with his brother Will invented and produced "Kellogg's Corn Flakes"; the sensational advertising campaign of these breakfasts in women's magazines has revolutionized the grocery. At the same time, Dr. D.H. Kellogg was religious to fanaticism and possessed the qualities of an excellent preacher.

Turning to the Davidovich hospital, we must add that in 1914, it already had an X-ray room, where the well-known in Kharkov roentgenologist Yu.A. Goldinger worked. By 1917, the hospital had its own chemical and bacteriological laboratory for analysis. Boris Spivakov certainly had a hand in expanding the services in these fields. In the city guide of 1917 , he was designated as a specialist not only for internal and nervous diseases but already for physical methods of treatment.

B.I. Spivakov, like P.A. Litsyn, were permanent employees of the Davidovich hospital; other doctors who worked in it, were replaced from time to time, especially in the years of war (1904-1905 and 1914). They were random people who did not reveal their skills, and there is no sense in monitoring their personnel assets. Thus, before the onset of the World War, the resident physicians of the clinic were doctors N.F. Burov and S.D. Fogelson (Fig. 7). But already in the guide

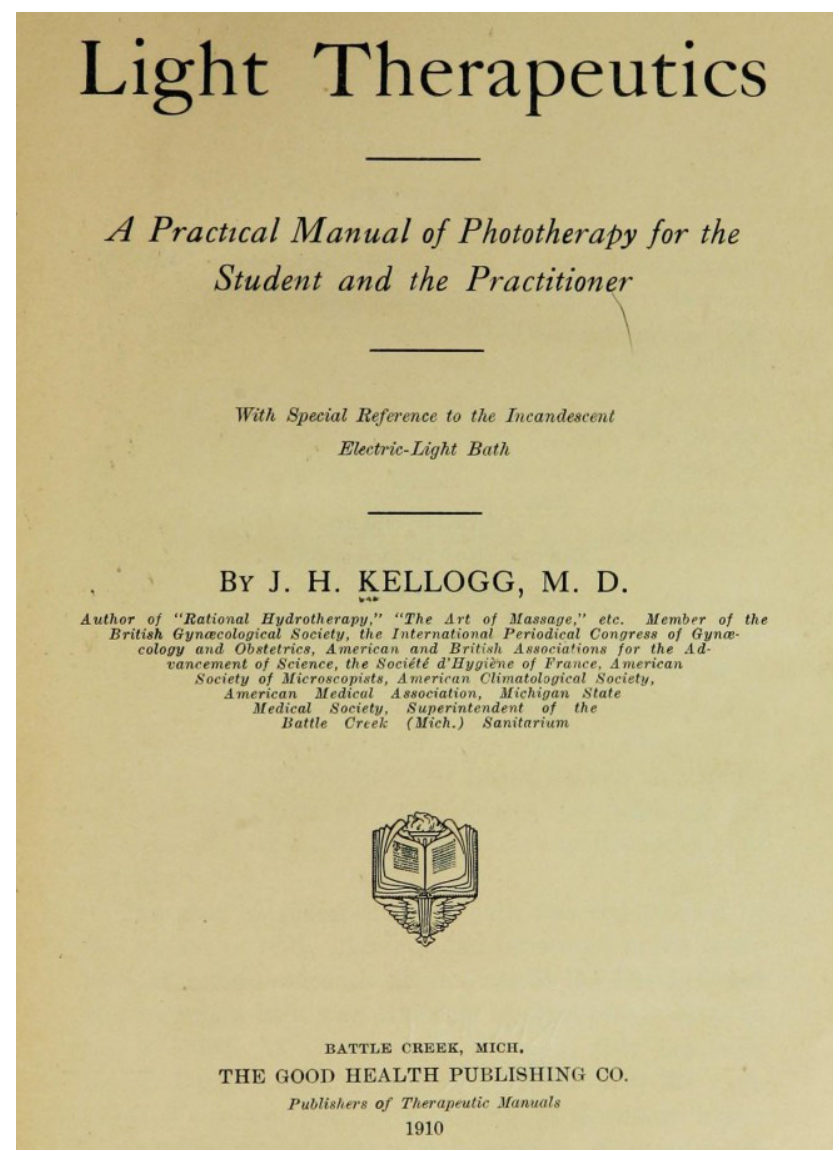

Fig. 6. American physician John Harvey Kellogg (left, source-Wikipedia) and title page of his work on light therapy (right) 
Лちчебница, водольчебница, электро-свьто-льчебница и Рентгеновскій кабинетъ, учрежд. докторомъ
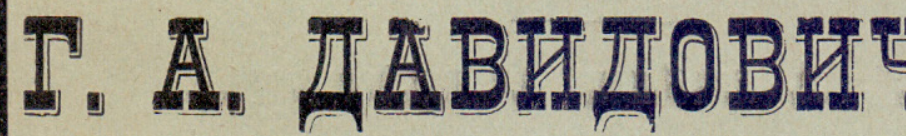

Харьковъ, Благовищенская ул., соб. домь 샤으 10-12.

ПРІЕМЪ БОЛЬНЫХЪ СТАЦІОНАРНЫХЪ И ПРИХОДЯЩИХЪ.

Льчебница

съ постоянными кроватями открыта для пріема больныхъ скими забольван. и разстройством обмтна вешеств (отиреніе, подагра сахарное мочеизнуреніе и хроническій ревматизмъ). Въ льчебницу больные принимаются какъ для льченія, такъ и для всъхъ видовъ изсльдованія, а также для клиническ. наблюденій и консультадій, необходимыхъ зъ цьљлях діагноза и плана льчченія.

Заразные, психич. и әпилептики вовсе не принимаются. При льчебниць постоянное дежурство врачей.

Завьд. львчебн. д-ръ П. А. Жииинг. Ординат. льчебн.д-ра Н. Ө. Буровъ и С. Д. Фогельсонг,

\section{ВОДОЛЬЧЕБНИЦА}

снабжена всьми новьйшими приспособленіями для гидро-бальнео-термотерапіи: ВТ томъ числь паровыя и суховоздушныя ванны, общія и частичныя (проф. Bier'a), частичныя грязевыя ванны, минеральныя п углекислыя ванны, искусств. еНарзанъ » и «Наугеймъ s. Примъненіе гидріатич. процедуръ производится подъ постояннымъ наблюденіемъ врача водольчебницы.

\section{ЭЛЕКТРО-СВЬТОЛЬЧЕБНИЦА}

оборудована приборами для полученія

гальванич., фарадич., статич., синусоид., пульсиров., токовъ высокаго напряжепія и большой частоты Тесла д’Арсонваля. апп. для діатерміи, приспособ. для гидро-электрич. ваннъ: двухгнбзд. и четырехгнђзд. системы д-ра Шнея, а также аппаратами для мъстнаго и общаго свъ̆тольченія.

Водольчебница и электро-свђтольчебница открыты круглый годъ.

Пріемкые часы для приходящихъ: мужчинъ отъ $8-10$ ч. утра и $6-8$ ч. веч., дамъ отъ $11-$ 12 ч. дня и 4-6 ч. веч. Врачг водо-ялектро-свпто-личебницы д-ро Б. I. Спиваково. РентГенОВСКіЙ КабИНеТЬ снабженъ новъйшими усовершенствованіями по 10-12 час. дня, 4-6 час веч въ экстренныхъ случаяхъ по соглашенію.

Завъдующій рентгеновскимъ каоин. д-ръ Ю. А. ГОЛЬДИНГЕРЪ.

ОтдБльный кабинетъ для врачебной гимнастики и массажа: ручного и вибраціоннаго.

Fig. 7. Advertising of the hospital Davidovichey in the Kharkov Medical Journal (1914)

"All Kharkov in the pocket" for 1915, V.E. Filips and G.K. Nagel were named as the resident physicians.

The clinic of Davidovich, as it usually happens, only lost from the revolutions and the Civil War, both with the Reds and with the Whites. 19.08.1919, when the city was occupied by Denikin's army, local newspapers reported: "The thieves robbed the apartment of the famous Kharkov doctor A. Davidovich at Blagoveshchenskaya Street, 12 . Property worth 65,000 rubles was stolen."

And the Bolsheviks, having occupied Kharkov at the end of the year, nationalized the clinic entirely, renamed it the 3rd working (Soviet) hospital for 40 beds. Despite this, the permanent staff of the clinic preferred cooperation with the expropriators to escape

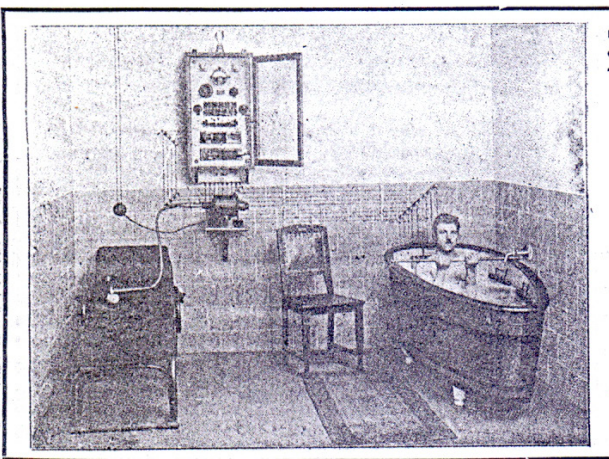

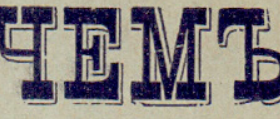
тоновъ.

from them. According to the guide, Pavel Anatsayevich Litsyn worked in the Soviet hospital as an ordinary doctor; and Boris Iosifovich Spivakov remained in the then capital of the Ukrainian SSR, who was finally re-qualified as a physiotherapist. [8] Even the heir of the founder of the clinic, Alexander Grigorievich Davidovich, worked as a doctor for nervous diseases in the 4th working polyclinic at Pushkinskaya str., 32.

In the years of the NEP it was time to restore and repair the long-standing idle light and ordinary baths of the 3rd Soviet hospital. Probably not coincidentally in the neighborhood, on the Ekaterinoslavskaya street (now named after Y.M. Sverdlov) a private "electro-medical and mechanical workshop" was opened, which specialized just on physiotherapy electric appliances (Fig. 8). And advertising of the corresponding devices of German production returned to the medical periodical publications of the USSR, which greatly increased in the 1920s.

It must be said that the Bolshevik government did not spare currency for the technical equipment of medicine and the development of science. As a result, in the second half of the 1920s the 3rd Soviet hospital gained deservedly the status of the "Physico-therapeutic institute" (as it was
Fig. 8. Advertising from the Kharkov journal "Medical Practice" (1924) 
written in the guides of that time) with an outpatient clinic, in other words, it became the Ukrainian Research Institute of Physiotherapy, which was described by Prof. L.D. Tondiy [1] in the article. That, of course, testified about the saved experience and authority of the medical institution which entered the period of maturity.

Today, the three-story building of the Davidovich's former clinic, which has not lost its external presentability for 120 years (Fig. 9), continues to serve health care: according to the signs, the Sanitary and epidemiological station of the Kharkov Line Department of the Southern Railway and the BAT (bioanalytical technologies) Medical Laboratory are located here. But physical methods of treatment are now not prescribed.

Since the thirties of the last century,

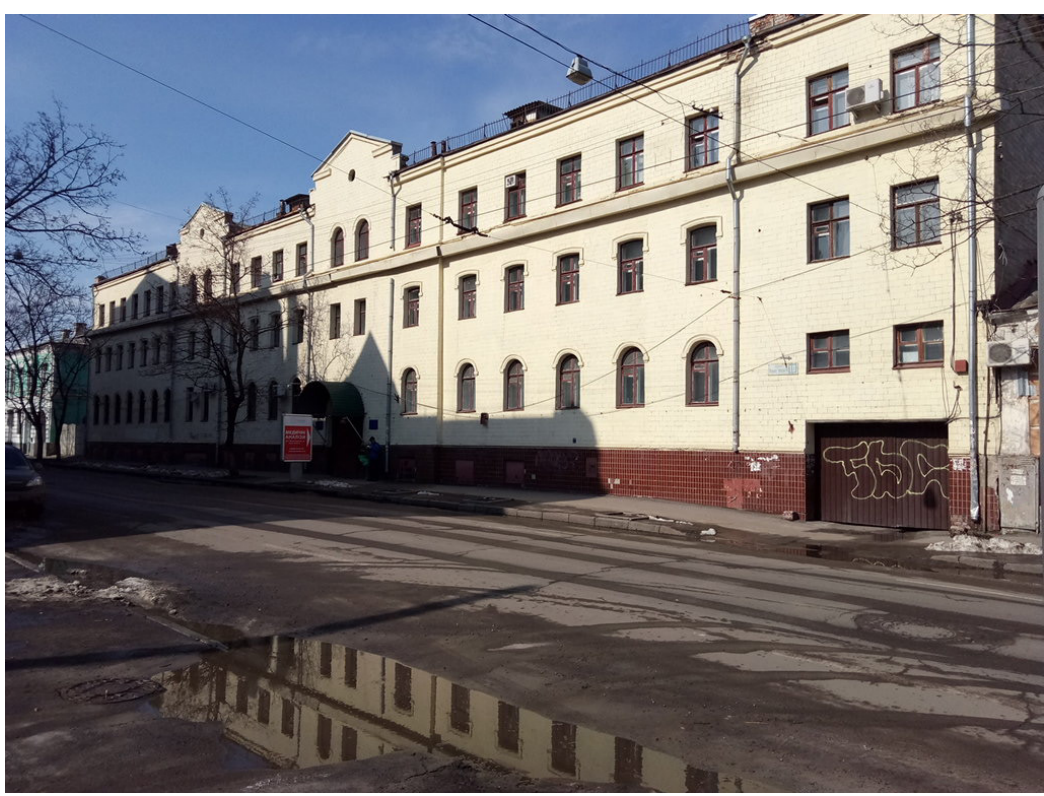

Fig. 9. The building of the former clinic of Davidovice on the street. K. Marx (Blagoveshchensk), 10. Source: yandex.ua/maps

3. Rusanov KV, Rusanova EG. "Iron light" of Dr. Sudeikin: the history of phototherapy in Kharkov. In: Materialyi 45-y Mezhdunar. nauchno-prakt. konf. Primenenie lazerov v meditsine i biologii [Materials of the 45th Internat. Scient. and Practic. Conf. Application of lasers in medicine and biology]; 2016 Oct 6-8; Harkiv-Bukovel. Harkiv: Petrov V.V. Publ.; 2016; p. 150-3. (in Russian)

4. Rusanov KV, Rusanova EG. The history of treatment with blue light in Kharkov. In: Materialyi 44-y Mezhdunar. nauchno-praktich. konf. Primenenie lazerov v meditsine i biologii; 2016 May 26-28; Harkiv. Harkiv: Petrov V.V. Publ.; 2016; p. 133-6. (in Russian)

5. Robak IYu. Orhanizatsiia okhorony zdorovia v Kharkovi za imperskoi doby (pochatok XVIII ct. - 1916 r.) [Healthcare Organization in Kharkiv during the Imperial Era Age (beginning of the 18th century - 1916)]. Kharkiv: Kharkov State Medical University Publ.; 2007. 346 p. (in Ukrainian)

6. Ustav chastnoy hirurgicheskoy lechebnitsyi s poliklinikoy doktora G.A. Davidovicha v g. Harkove [The charter of a private surgical hospital with a polyclinic of Dr. G.A. Davidovich in the city of Kharkov]. 1895. 7 p. (in Russian)

7. Anikin MM, Varserver GS. Osnovyi fizioterapii: posobie dlya vrachey i studentov [Fundamentals of Physiotherapy: a guide for physicians and students]. Moscow - Leningrad: Biomedgiz Publ.; 1936. 722 p. (in Russian)

8. Spisok meditsinskih vrachey S.S.S.R. na 1 yanvarya $1924 \mathrm{~g}$. [List of medical doctors of USSR on January 1, 1924]. Moscow: - Publ. of the People's Commissariat of Health, RSFSR; 1925. 827 p. (in Russian)

1. Tondiy LD. On the development of light-laser therapy in Slobozhanshchina . Fotobiol. ta fotomed. [Photobiol. and photomed.] 1998;1:126-30. (in Russian)

2. Rusanov KV, Rusanova EG. Berezovsky mineral waters in the 1860s. In: Materialy IV Mizhnar. nauk. internet-konf. Istorychni, ekonomichni, sotsialno-filosofski ta osvitni aspekty rozvytku okhorony zdorovia [Materials of the IV Intern. scien. Internet conf. Historical, economical, socio-philosophical and educational aspects of health care development]; 2016 Nov 1-4; Kharkiv: Kolehium Publ.; 2016; p. 47-51; Rusanova EG, Rusanov KV. Lukyan Gurvich is a pioneer of the Berezovsky mineral waters . Ibid; p. 51-5. (in Russian)

9. Meditsinskiy ukazatel g. Harkova [Medical guide of Kharkov]. The publication of the Blagoveshchensk pharmacy of S.B. Chudnovsky. Harkov; 1901. 82 p. (in Russian)

10. Zinchenko EK, Tondiy LD, Vasilyeva-Linetskaya LYa, Rozdilskaya ON, Nechipurenko ON, Kas IS, et al. . Department of Physiotherapy, Balneology and Restorative Medicine of the Kharkov Medical Academy of Postgraduate Education is 90 years. Shidnoevrop. zhurn. vnutrishnoyi ta simeynoyi med. [The Eastern Europ.Journal of Internal Med. and Family Med.]. 2017;2:54-61. (in Russian) 